\title{
The Study on Economy Status of University Academy
}

\author{
Manli Zou ${ }^{1, a}$ \\ ${ }^{1}$ Nanyang Institute of Technology, Nanyang City, Henan Province, Yangtze River Road 80 \\ hunter2011@foxmail.com
}

Keywords: University, Academic,Economy

\begin{abstract}
Academic education is the cross product of education and ecology. Good academic ecology in universities is not only beneficial to full play the important functions of social services and economic development, but also conducive to the prosperity and development of college scientific research. This paper describes the true state of contemporary academic ecology of Chinese universities from the five academic perspectives such as academic innovation atmosphere, academic atmosphere, academic institutional management, academic achievements evaluation, academic innovation incentive hoping to provide some ideas for the study of academic problems of colleges and universities.
\end{abstract}

\section{Introduction}

Ecological originally referred to the state under certain biological survival and development of the natural environment, and the relationship between them and between it and the environment interlocking. Today, the "Ecology" category of the term more widely involved in vision research academic problems down ecology of higher education, not only provides a new way of thinking for the higher education researchers, but also provides our research universities academic issues the new methodology guidance.

Good universities academic ecology is not only beneficial to give full play the important functions of its social services, economic development, but also conducive to the prosperity and development of college scientific research itself. However, the advent of the current academic ecology in some Chinese universities violate the law of development of higher education of adverse factors, resulting in bubble Academic impulsiveness and academic behind the prosperity abound.

\section{The Academic Innovation Atmosphere is Not Thick}

The negative factors in Chinese traditional culture are still restricting the academic ecology construction of current university. Famous British scholar Joseph Needham in his book "History of Science and Technology China" had asked: "? Although the ancient Chinese science and technology for human development has made many important contributions, but why science and the industrial revolution did not happen in modern China," the Chinese nation is a great wise nation, in science and technology had been brilliant stars and brilliant. However, we must also see that on the one hand, the ancient Chinese philosophy heavy savvy, heavy experience, although the formation of a more advanced way of thinking, but has not formed a rigorous scientific theoretical system. Ancient Chinese philosophy used to "push the Heaven and the Ming personnel," focus only on the morality of building construction and the lack of a rational basis for quantitative scientific analysis. So we say, the ancient Chinese science and technology, trace in the end, but the product of empirical, although it leads the world for thousands of years, but missed and prosperity of modern technology. On the other hand, the ancient Chinese peasant economy closed and conservative, is like a deep imprint, affecting the development of the country, shaping people's character. Enslaved under the highly centralized system of "three cardinal guides and the five permanent members", "excellent learning Shi" alienation of the "official position" is still affecting people's life and values. Academic research in the "mouthpiece", academic echelon "only on", "only leader" seriously restricting the build normal 
academic atmosphere; for some time, academic or even "WTO" springboard "research talents were Shi" in the current university academics have been uncommon.

The academic impetuous and academic irritable have become the new normal in academic circles by the impact of market economy. In recent years, governments at all levels eclectic recruit talent, enjoy the corresponding research and treatment depending on the talent level, political status, remuneration, etc., in the interests of the temptation in front of a large number of researchers to pursue high competing titles, highly educated, even gilded abroad, some universities and research institutions in order to have the number of "high-level personnel" proud, researchers for the benefit of the aura and Aureole honors, how to have a quiet, indifferent academic mentality in the desperate seek a degree, making monographs, the results in this scrambling research environment?

At present, China is in the economic restructuring and development, a critical period of industrial structure optimization, the good economic situation led some people get rich first up, there is a luxury car, the villas, flamboyant, there are some people within the system, and careful management to the bureau level, the level of even the departmental level, in front of the driver, after the secretary, next to people flattery, flatter constantly, in this kind of money, status Heroes environment, some academic researchers do not consider themselves "money "way, no career, no purpose, no studies also take a back seat for a lifetime," Yang second, "Ever tempted beyond the academic fast-paced world, distracted, sit down, no less than quiet heart, do not mind academic; there are some who always carries a impulsiveness, have simple ideas and work to complete the task, to cope with errands, can not ease down, terrible research; some people obsessed with "Academic" bite off more than seek large, the pursuit of results, the pursuit of fame, apply awards, fame, called "academic master", indeed "academic traffickers."

\section{The Academic Atmosphere is Impure}

The refined utilitarianism has seriously hampered the building of a good academic ecological environment. In recent years, with the core of the market economy, gradual consolidation, utilitarian view of life, values the rapid expansion of exquisite egoism and utilitarianism has become the only driving force in intellectual elites represented by words and deeds. This group has a high IQ, have received higher education, at the same time, they experience too "sophisticated aging", most of them good walk within the system to maximize its own interests.

It is not shortage of fine utilitarian in colleges and universities. It is often said, the university campus is the last pure land on society and academic hall is the most admired church. In recent years, however, the university academics of endless academic anomie, academic misconduct, academic corruption, which have allowed the sacred temple of people's minds collapsed, turned ivory tower academics from the Vanity Fair. Some current research universities, academic, professional title assessment and other academic activities by level, by rank, by seniority, by honor; these irrational, utilitarian academic evaluation system, a direct result of everyone impatient, impetuous, quick success, relations flooded; the pursuit of evaluation, interest, money, power and scientific research has been very intimate and mutually reinforcing; most of the scientific research of the time and effort spent running relationship to the project, identification of the required procedures, and even academic fraud, plagiarism and other achievements, many teachers, academics quick success, opportunistic, fame, there is no dignity at all academic.

Academic ecological imbalance not only against the academic spirit, but also directly affect the scientific innovation. In order to comment on the title, the teachers desperately piled papers, Latin America hang project, only the number of scientific standards; To declare the research, teachers dinners, walking opportunities, please say hello leadership, etc. Such situations are not uncommon in the Chinese universities; also there are currently a number of important research policy declaration, weight assessment, heavy supervision, heavy results, heavy awards, heavy honor, a serious violation of academic creativity inherent law, resulting in a short-term mentality and impetuous behavior, resulting in significant academic innovation difficult results. Utilitarianism refracted into college talent cultivation up, on the performance of colleges and universities in the pursuit of students, 
enrollment pursuit, the pursuit of employment, over to meet the market demand and economic development, curriculum, professional setting "wind down" in order to pursue the interests of the largest school oriented, ignoring comprehensive, academic, basic, humanities curriculum system even in the cold of course omit setting. In recent years, national universities have begun to reflect on this phenomenon. A survey report by the US Department of Education states: absent humanities, making students' moral creativity and interpersonal skills greatly reduced. Our scholars also began to reflect: After the founding of new China, in order to quickly catch up with the industrial civilization, higher education ignored the spiritual needs of young students, the students were "learn physics and chemistry, traveled world are not afraid" of such practical reminders ahead of Education cooked, how can we expect them to be the best successor to academic research, academic innovation.

Under the administrative institutions of higher education, academic democracy is still difficult to obtain. Objectively speaking, China's current lack of contending academia and the scientific community has not yet formed inside of sufficient academic democracy have a great relationship. Under China's current management system of higher education, universities, research institutions by the "executive" of the impact of deep, over the years, our academic leadership accustomed to treat the attitude of experts and scholars in many achievements, three from the four virtues, treat leadership expert and academic point of view is to learn and understand, not refute, not questioned, but not out of his right.

In fact, people's creativity only in the free, relaxed environment to gushing out, under the encouragement and appreciation, cherish and care, will play vividly. Only in the academic environment of freedom, democracy and the scholars can feel free to express their views, the leading position, contending necessarily bring prosperity and a good harvest is academic. Academic mouthpiece, academic tyranny, can not tolerate challenges, can not tolerate different opinions, or dare to challenge, dare to put forward different views, then a backwater of academic research only.

One of the most valuable qualities is the maverick scholar, not superstitious, not blind obedience. The ancients said, "Believe everything the book as no book", only not superstitious authority, a scholar will not bow to concede defeat to the authority, parrot, he will get down to the bold pursuit of truth; they do not follow blindly, we will not ride in the wall around the sidelines and become flatter scholars. No democratic environment, faith in democracy for support, to uphold the truth, seek truth will be suppressed and destroyed, once scholars have learned only "authoritative scholars," the lead, groveling, submissive, it will only be immobility, how to contending, flourishing?

The academic corruption is eroding the academic ecology in universities. Academic corruption refers to the use of academic resources to seek non-legitimate interests or improper use of academic resources to reap benefits, such as the right to learn trading, learn trading money, school colors transactions. Academic corruption make academic research toward alienation, it challenges being true scholar dignity and rights, breaking the moral bottom line of academic research, more important is the destruction of academic ecological construction, hinder the growth of academic talent.

Recent exposure to the academician academic corruption, national famous experts, scholars, down to the Academic team, the research achievements can be described as different as day, but it means a similar academic corruption. Thesis plagiarism, outcomes fame, fake science and technology innovation, academic injection, academic accreditation status of academic strange unspoken rules, where can have, nothing is there, everywhere in the academic field "hidden rules" of academic corruption tolerance and even connived to the extreme. This not only causes a lot of wasted time and money, but also generated a lot of academic bubble, academic garbage, causing confusion in academia, but also the truly valuable academic devaluation.

The academic environment pollution and vandalism, and ultimately harm the academic ecological sustainability, resulting in the academic field "bad money drive out good money." In recent years, Chinese academic scandals, scholars report academics, students report a teacher, academic corruption intensified, three Academy of Cheung Kong Scholars, university leaders, business executives, academic giants the other party you debut, it was a "fake" for the music, but "fake person" who was also fake, more and more scandals, more and more big joke. Academic giants need to "quote", "learn" 
the results of others, in the absence of scientific research, there is no great pressure titles, most scholars within universities, ordinary teacher, what confidence innovation, independent creation.

\section{The Poor Academic Institutional Management}

The management system of the affected countries, academic research has also been our management top-down national administrative units, which is scientific and technological innovation of a serious shortage of personnel is an important reason.

In colleges and universities, launched, progress, knot, supervision and evaluation of scientific research, we have accepted the coordination and management of higher authorities and school administrative power, but also basic research through a number of quantitative indicators to measure. In order to promote the comprehensive development of the school's research work, although the university have developed a quantitative, scientific and objective academic assessment, academic awards, funded academic institutions (and associated professional titles evaluation, welfare systems, etc.), the intensity of investment is quite large; however, because the quantitative assessment, rewards and funding system there is a deviation in the guide, it is also contrary to the academic research in largely self-rule. According to the executive level to determine the quality of academic publications; the number of projects in order to identify the level of scientific research ability; to approve research effort to urge, arouse enthusiasm among other measures the implementation of scientific research, so that the teacher can not really devote themselves to academic stop and take a long time to study the accumulation of topics, but more adapted to the current academic management system of people more like a duck, fame and fortune, running relationship, pull items, hanging issue, even at the plagiarism, but the bulk of scientific research out.

Administration and academic management, academic and confused the power to make the knowledge standard gave way to power-oriented; scientific standard gave way to the utilitarian standard; spirit gave way to substance-based standard. Blow to academic scholars enthusiasm, the temptation for them to concentrate improve interpersonal relationships, using trickery to compete for the top interest, serious injury and sitting on the bench against the earnest, really engage in scientific research and teacher enthusiasm.

\section{The Injustice of Academic Achievement Evaluation}

Academic evaluation system is to identify academic achievement, academic quality audit, guiding the academic direction of a special regime. China's current system of standardized academic evaluation of humanities and social science research and promotion has a huge role, but it also has neglected the quality of quantification, closer to the administrative level, profit-oriented academic and other ills spawned foam.

The quantization of academic achievements ignores the "quality" requirements. Many research universities audit workload, job classification has the "quantity" absolute tendencies, highlighting the number of articles, the number of items, the number of scientific research achievements, determine the research capabilities. So the research on job classification and workload assessment becomes a game quantitative evaluation of talent is not in accordance with the academic standards and contributions, but according to the number of discrimination. Everyone made school for research and research for Minato digital bustle desperately, in which heavy "quantity" is not heavy under "quality" academic evaluation system constraints and we can cultivate academic master imagined.

The academic research is closer to the administrative level. The impact of academic research by the official standard is already an indisputable fact. Level recognized academic journals, the importance of the project by the relevant administrative unit to decide. What kind of papers published in academic journals, the project's topic is the National Social Science Fund or provincial social science projects, marked the completion of one so-called scientific research strength and research standards. Academic and scientific research should not linked with any administrative level, but the 
executive power in the academic strength as compared to the elephants and ants, have absolute capability, so obediently obey only academic strength, orders from the executive power.

The quick success spawned academic bubble. As the name suggests, the so-called bubble academic scholarship that is actually no real scientific value, in fact, some of the academic bubble "body heart in Cao Ying Han" in the name of academic scholars under the banner of a vicious destruction of Academic Ecology. As one of the iconic products of academic misconduct, even though many people know Foamy no academic value, but this music is not he still the main reason is that the real scientific research, ten years hard grind a "sword" and foam academic who was able to "results" numerous, awards, benefits, fame got everything, as the results of the gold content of the level of scientific research to improve the level of the school or without advance whether the outcome may translate into local economic benefits, it is not in considered.

\section{Academic Innovation Incentive Isn't Enough}

This concept is used to motivate management refers to a variety of effective ways to mobilize the enthusiasm and creativity of employees, so that employees try hard to fulfill the organization's mission to achieve organizational goals.

I must admit, for the experts of painstaking research, the innovative scientific research undoubtedly their most supreme reward hard work. However, the appropriate material or spiritual motivation as academic research activities propellant, to protect the enthusiasm of scholars to mobilize their creativity, the potential of a huge driving force for the release of better academic services.

Currently, many universities one academic incentive mechanism is not perfect, incentives relatively simple, usually presents spiritual rewards light weight material rewards. While we engage in academic research purpose is not to engage in money, but in the tide of market economy, "engaged in the atomic bomb as selling tea" is not the result we want to see. Second, the incentive mechanism is not fair, not transparent enough. Or reward academic team leaders tend to dampen the enthusiasm of other participants; or simply eat the "iron rice bowl", egalitarianism, reward for everyone regardless of contribution, the results we all engage in boring. Three, through administrative means to carry out academic incentives, higher education has also been criticized by many researchers. Experts in certain academic fields has made some achievements, the state and units or for retaining talent, with good talent to consider, will be promoted to an official academic elite. The result is often the official did not do, learning also abandoned. For indeed there is a significant contribution to academics, spiritual rewards, material rewards can be, but it is best not to the administration of incentives for young people to avoid establishing a kind of "research and gifted to official" role models, two "is official Academic grave "Having extreme, but it is also a lot of experts and scholars to lose themselves in the painful price in exchange for the best advice.

\section{Acknowledgements}

Fund Project: The paper belongs to the "Research of Crucial Problems of Applied Technology Talents Training Mode Reform and Innovation In Transformation College " in Henan Higher Education Reform Project, project number is 2014SJGLX066; National Educational Science Planning 2009 primary and secondary schools and Education Research special issue, Educational Department key project "Construction of College Students' Eco-Campus ", project number is GEA090024.

\section{References}

[1] D.H. Liu, Fundamental return path of academic spirit: academic system reconstruction, J. Hunan Normal University Education Science, 2009.

[2] L.J. Tong, W.D. Meng. The postgraduate academic innovation incentives alienation and 
governance research in perspective of academic ecology, J. Degrees and Graduate Education, 2014.

[3] H.X. Zhang, University management innovation: in perspective of academic organizations, J. Chongqing Higher Education Research, 2014.

[4] Z.M. Wang. The cultural interpretation of "Needham", J. Liaoning Administration College,2008.

[5] Y.M. Chen, Some problems and solutions in professional titles work under the new situation - in case of Fujian Province, J. Chifeng College: Natural Sciences, 2014.

[6] Y.L. Zhou, Research on assurance system of postgraduate academic moral - taking agricultural students as an example, D. Huazhong Agricultural University, 2010.

[7] Y.Yan. Comparison of science and technology modes of ancient Chinese and Greece, D. Hebei University, 2007.

[8] D.F. Tao, The structural transformation of Chinese intellectuals of new era three decades, J. Chinese Book Review, 2008.

[9] C.H. Qiu, Mechanism innovation of knowledge production and literature research, J. Contemporary Literature, 2007.

[10] Z.L. Tong, The root of postgraduate research fraud is the academic ecology [EB / OL] China Youth Daily, 2013-01-30.http: //zqb.cyol.com/html/2013-01/30/nw.D110000zgqnb_20130130_203.htm.

[11] Z.L. Tong, Give academic a clean ecological environment [EB / OL] Nanfang Daily digital edition, 2012-05-25.http: //epaper.southcn.com/nfdaily/html/2012-05/25/ content_7087715.htm.

[12] G.Y. Zhu, Dialogue with Professor Liu in Tsinghua Institute - Academic Ecology of our time [EB / OL] Beijing News electronic version, 2012-11-10.http://epaper.bjnews.com.cn/html/ 2012-11 / 10 /content_389084.htm? div $=-1$. 